\title{
К.В. Осипова
}

\section{НАЗВАНИЯ СПИРТНЫХ НАПИТКОВ НА РУССКОМ СЕВЕРЕ: ЭТИМОЛОГО-ЭТНОЛИНГВИСТИЧЕСКИЙ АНАЛИЗ ${ }^{1}$}

\begin{abstract}
Рассматриваются наименования крепких спиртных напитков, распространенные на территории Русского Севера. Основными источниками материала послужили лексические картотеки Топонимической экспедици Уральского федерального университета. Автор прослеживает пути проникновения названий крепких алкогольных напитков в севернорусские говоры, определяет ареал их распространения и генетические связи. Большая часть рассмотренных диалектных лексем заимствована из просторечия и жаргона.

Ключевые слова: русский язык, диалектология, жаргон, просторечие, Русский Север, напитки, алкоголь, этимология, этнолингвистика.
\end{abstract}

Данная статья родилась как серия этимолого-мотивационных комментариев к находкам Топонимической экспедиции Уральского федерального университета, сотрудниками которой на протяжении многих лет собирались диалектные материалы на территории Русского Севера - Архангельской, Вологодской и Костромской областей. Среди собранных лингвистических данных оказалось немало названий, связанных с темой приготовления и употребления хмельных напитков. Представленный в Картотеках [1, 2] лексический материал позволяет говорить о том, что крестьяне Русского Севера употребляли три основных типа алкогольных напитков - пиво, брагу и самогон (водку). Наиболее архаичной была традиция пивоварения, которая отличала пищевую культуру Русского Севера от других регионов России: лексика пивоварения представлена в основном исконными словами, которые называют этапы производства, особенности ингредиентов, качество сваренного пива и пр. Следующая лексическая группа - наименования браги: как и пиво, брагу крестьяне варили сами и традиции ее приготовления также довольно архаичны. По сравнению с пивом брага считалась напитком второго сорта и не играла той обрядовой роли, которая отводилась пиву. При этом специфика ее названий состоит в большом проценте экспрессивных и метафорических обозначений (ср. севернорус. $\partial y$ ранда, кумушка, шатун и пр. [1, 2]). И наконец, третья группа - это названия вина, водки, самогона и других спиртных напитков, которые редко готовились дома, но чаще всего приобретались - в кабаках, магазинах или у местных «самогонщиков».

\footnotetext{
${ }^{1}$ Исследование выполнено при поддержке гранта РНФ «Контактные и генетические связи севернорусской лексики и ономастики» (проект 17-18-01351).
} 
Представленная в современных говорах лексика, называющая крепкие спиртные напитки, начала формироваться в XIX в., существенно расширился этот пласт в XX в., когда на Русском Севере стала постепенно сходить на нет традиция пивоварения и возросла доля покупаемых напитков. В связи с тем, что водка и вино были завозной продукцией, вместе с появлением этих товаров в севернорусской деревне в диалект проникала новая лексика, источником которой служили городское просторечие и жаргон. Одна из особенностей географического распространения подобных лексем заключалась в том, что в основном они представляли собой точечные номинации, которые бытовали в одном или нескольких районах, и лишь некоторые из них охватывали широкую территорию. По всей видимости, это было связано с локальностью продаж и поставок алкогольных напитков.

Если традиции, связанные с пивоварением на Русском Севере, исследованы уже довольно основательно (см., например, [3-7]), то лексика и обычаи употребления иных спиртных напитков на этой территории практически не изучались. В предлагаемой статье мы постараемся проследить пути проникновения названий крепких алкогольных напитков в севернорусские говоры, определить их ареал и генетические связи. Учитывая большое количество собранных наименований, в рамках данного исследования будут рассмотрены прежде всего те слова, источником которых послужили городское просторечие или жаргон. Эта лексика представляет особый интерес для изучения проблемы соотношения «слов и вещей», поскольку помогает проследить процесс появления и распространения реалий, сопровождаемый зарождением слова в русском языке, а также пронаблюдать последующее проникновение новых реалий в традиционный мир севернорусских крестьян и адаптацию диалектом новых слов из чужеродной языковой среды. Именно поэтому семантико-мотивационные и этимологические комментарии, составляющие основу статьи, соединяются с наблюдениями историко-культурного характера.

Ханжа. В Архангельской и Вологодской областях записано слово ханжа́ 'домашняя брага; самогон' [1]. Так называли алкогольный напиток, более крепкий, чем пиво, который по своим вкусовым качествам обычно ценился ниже: «Бардома, ханжа, брага - вот где голова-то болит»; «Ханжа - головоломка настоящая, с души рвет с нее» (волог. к-г.) ${ }^{1}$; «Отбросы от пива дак ханжа, если самогонка не получилась тоже» (волог. м-реч.); «Ханжу делают, как брага, еще чиквас называют (арх. лен.); «Варили для мужиков пьяно пиво, ханжой называлось, а для женщин непьяно» (арх. прим.) [Там же]. В отличие от пива, варка которого требовала особых умений и была затратной по времени, приготовить ханжу было гораздо проще: «Ханьжа - подвид пива, только меньше соборок <приготовлений, хлопот>. На пиво-то много собирать - кадки да лагуны да, а ханьжа, брага-то

\footnotetext{
${ }^{1}$ Расшифровка сокращений в названиях районов приводится в конце статьи, сокращения в названиях областей даются в соответствии со Словарем русских народных говоров [8].
} 
эта, быстрее» (волог. ник.) [1]. Как заменитель пива в XX в. ханжу иногда готовили к сельским праздникам и свадьбам: «На свадьбы, на праздники всегда варили ханжу» (арх. холм.). Судя по материалам Картотеки [Там же], ханжу не только делали сами, но и привозили из города.

Слово ханжа в севернорусских говорах можно соотнести с жаргонным ханжа 'алкогольный напиток низкого качества', которое происходит от заимствованного названия китайской водки из проса или чумизы - ха́ншин (ханши́на) [9. С. 635]. Согласно А.Е. Аникину ха́ншин 'китайская водка', ханчи́на 'китайская неочищенная водка' восходит (через бурят./монг. по-

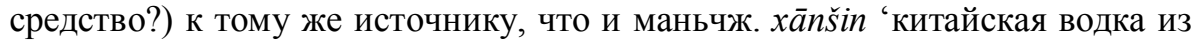
гаоляна', бурят. хааншан 'китайская водка' [Там же]. Известно, что уже с середины XIX в. ханшин контрабандой ввозили на Дальний Восток России из Китая: он пользовался популярностью в силу дешевизны, а также дефицита российской продукции или ее полного отсутствия во времена «сухого закона».

По свидетельству военного писателя М.В. Грулева, который в 1890-е гг. возглавлял научную экспедицию в Маньчжурию, «ханшин в большом количестве вывозится контрабандным путем на Амур, где раскупается нашими прибрежными казаками и кочующими инородцами, так как продается в несколько раз дешевле нашей водки: кроме того, в глазах усердных потребителей спиртных напитков, ханшин имеет еще то своеобразное преимущество перед водкой, что после опьянения от ханшина “выпил воды стакан и опять пьян”, так что, по словам казаков, “опохмелиться после ханшина ничего не стоит”» (М.В. Грулев. Из поездки в Маньчжурию // Исторический вестник. 1900) ${ }^{1}$. В художественной литературе, территориально связанной с Дальним Востоком, ханшин упоминается как напиток, который солдаты пили от безысходности при нехватке водки во время Русско-японской войны: «Удар по самолюбию в маньчжурской армии от сдачи Порт-Артура ощущался слабее, чем в России, - войска не могли забыть крови, бесцельно пролитой за его спасение. Водки недоставало, пили “ханшин”. Офицеры в тылу играли в карты» (А.А. Игнатьев. Пятьдесят лет в строю. Кн. 1-2. 1947-1953) Проникновение ханшина на территорию России, его широкое распространение, повсеместное употребление слова ханшин и образованного от него ханжа было связано именно с событиями Русско-японской войны 1904-1905 гг.: возвратившиеся домой русские солдаты «популяризировали» слово в разных регионах России.

По наблюдению Е.А. Оглезневой, «главной особенностью регионального языкового существования на Дальнем Востоке России в 20-30-е гг. $\mathrm{XX}$ в. было китайское присутствие в нем. Это проявлялось, в частности, в активном использовании специфической регионально окрашенной лексики в русском языке дальневосточников - наличие в нем своеобразной “китайской ноты”» [11. С. 128]. На территории Приамурья бытовало несколько

\footnotetext{
${ }^{1}$ Здесь и далее тексты публицистики и художественной литературы цитируются по НКРЯ [10].
} 
вариантов названий китайской водки - хан(b)жа, хан(ь)жина: «У китайцев была ханжа, брали ханжу у них»; «Привозят ящик ханжины вместо водки» [11. С. 132], ханá: «Ханой китайскую водку звали», ханчи́на, хома́: «Раньше все больше хому пили, такая водка была» [12. С. 317]. Встречаются однокоренные лексемы и в других сибирских говорах, ср. новосиб. хана́, ха́нка 'самогон': «Ханкой её называли и ханой, вот самое самогонка любая, старики еще зовут так» [13. Т. 5. С. 203], Респ. Бурят. ха́нчина, ханша́ 'китайская неочищенная водка': «Раньше ханчину возили из Монголии»; «Ханшу хоть и по дешевке покупали, да черт ее пей. Пахнет она шибко», омск. ха́ньжа 'самогон': «Парни ханьжу принесут на вечеринку, а мы закуску» [Там же. С. 204]. К этому же гнезду относится томск. хана́ 'лекарство (какое?)': «А перво болела все, как асмой болела. А пила все наставляла - хана была раньше синя. Просто как шпирт. Она стручковым красным перцем наставляла» [14. Т. 7. С. 185] - очевидно, речь идет о лечебной настойке на спирте.

Таким образом, в русском языке слово ха́нши́н (ха́нчи́на) обрело несколько фонетико-словообразовательных вариантов. Форму хан(ь)жина можно рассматривать как результат контактной ассимиляции, озвончения $u$ на русской почве в ха́нши́н (ха́нчи́на). Усечение основы в вариантах ханьжá, ханша́, вероятно, возникло в русском языке позднее под влиянием общенародного ханжа. Формы хана́, ха́нка 'самогон, суррогатный алкоголь', которые синхронно представлены на восточносибирской и приамурской территории, по всей вероятности, также восходят к китайскому ханшин 'водка из проса или чумизы', фонетически трансформированному в жаргоне и просторечии. Родство слов ханка, ханыга, хановка и ханжа, ханшин 'самогон' признает А.Е. Аникин [15. Вып. 10. С. 70]. Из русского языка слово проникло в украинский и польский языки, где встречается в вариантах укр. диал. ганджа́ 'денатурированный древесный спирт; некачественная водка', ганжа́, ханжа́, ханьжа́, ханджа́, польск. chandża [Там же]. При этом семантическое развитие слова ('китайская водка' $\rightarrow$ 'суррогатный алкоголь') вполне объяснимо: поскольку ввозимый из Китая ханшин был напитком низкого качества, со временем так стали называть всякий суррогатный алкогольный напиток.

В значении 'алкогольный напиток из денатурированного спирта' слово ханжа широко употреблялось в России начала XX в. Исходя из количества его упоминаний в публицистике и текстах художественной литературы, наибольшее распространение этот напиток получил именно в 1910-1920-е гг. Публицистика того времени была вовлечена в антиалкогольную кампанию, развернувшуюся с началом Первой мировой войны и сосредоточенную на борьбе с суррогатным алкоголем, главным образом с ханжой, употребление которой становилось причиной массовых отравлений. Известно, что во времена «сухого закона», объявленного в период Первой мировой войны, отмечался рост смертности от ханжи, которая «была самым популярным напитком среди алкоголиков и представляла собой разбавленный денатурированный спирт (растворитель на основе этилового спирта-сырца, пред- 
назначенный для снятия лаков)» [16. С. 133]. В книге психиатра Н. Тяпугина утверждается, что «на смену “казенке" и "мерзавчику" шло тайное винокурение с его “самоплясом” (так называют в народе самогонку), шло суррогатное пьянство с “ханжой”, политурой и прочими отравами, отнимая у народа блага трезвости» (Н. Тяпугин. Народные заблуждения и научная правда об алкоголе. 1926). Об актуальности проблемы «суррогатного» алкоголизма и действиях государства говорили заголовки газет 1915-1916 гг.: «Борьба с “ханжой”» («Раннее утро». 1915.03.03), «Борьба с отравлением населения» («Русское слово». 1915.03.19), «Еще фабрика ханжи» («Петроградский листок». 1915.03.30), «Новый денатурат» («Московская копейка». 1915.05.10), «Борьба с пьянством» («Трудовая копейка». 1915.10.06). Городская пресса писала о том, как собираются сведения о торговле суррогатным спиртным («Раннее утро» (1915.03.03)), об облавах на продавцов ханжи, которые, по словам корреспондентов, были виновны в спаивании суррогатным алкоголем солдат на Ходынском поле («Вечерний курьер». 1916.04.29), о продажах ханжи в ресторанах («Вечерняя газета». Киев. 1915.01.26), о разоблачении фабрик по производству ханжи («Петроградский листок». 1915.03.30; «Вечерняя газета». Киев. 1915.01.18). Перечисленные издания относились к разряду дешевых, соответственно, основным адресатом статей в них были горожане с самым низким достатком, из-за дороговизны или отсутствия качественного спиртного перешедшие на питье суррогата: «Таким образом, если барин насыщается в ресторане, а “простак” лакает ханжу где-нибудь на Хитровом, то среднему обывателю доступно и легко было угощаться парфюмерными изделиями» (С. Рубин. На лету // «Вечерний курьер». Москва. 1915.07.29). В борьбу с суррогатным алкоголем был вовлечен и В.В. Маяковский, которому принадлежит лозунг, размещенный на плакате авторства А. Родченко: «Трехгорное пиво выгонит вон и ханжу, и самогон! Моссельпром». Судя по дате выпуска плаката (1925 г.), он был приурочен к возобновлению производства пива на московском Трехгорном пивоваренном заводе в 1923 г., который со времени выхода «сухого закона» переориентировали на выпуск безалкогольной продукции. По замечанию И. Старкова, опубликовавшего этот плакат на сайте «Arzamas», «бутылки с ханжой часто взрывались - такой взрыв как раз изображен на плакате в качестве доказательства в пользу трехгорного пива» [17].

Употребление ханжи стало знаком уличной удали и бесшабашности: например, в книге «Дом веселых нищих» писателя Г.Г. Белых (1930) «шкет отчаянный» Васька «хвастался, что умеет пить ханжу, но этому ребята не особенно верили». Ханжа связывалась и с представлениями о моральной деградации и асоциальном поведении, ср.: «Отец распутничает, пьет ханжу, бьет вас, гонит вон, тащит к своей любезной все из дома» (В.Ф. Майстрах. Полезные советы. Ответы на вопросы подписчиков «Трудовой Копейки» // «Трудовая копейка». 1915.03.23); «И вообще в самой мягкой форме дали мне понять, что я совершаю явно неприличный поступок, вроде того, как если бы среди всеобщей трезвости я 
ханжина нализался» (Л.Н. Андреев. Иго войны. 1916). Поскольку суррогатный алкоголь пили в основном бедные слои населения, ханжа воспринималась как часть образа пришедших к власти социальных низов: «...новые самодержцы торгуют выданными им казенными сапогами и штанами, щелкают подсолнушки, услаждаются ханжой, испражняются с крыш вагонов...» (Ф.Д. Крюков. Новым строем // «Русские ведомости». 1917). Для И.А. Бунина в «Окаянных днях» употребление ханжи стало атрибутом «новой литературной низости, ниже которой падать, кажется, уже некуда: открылась в гнуснейшем кабаке какая-то "Музыкальная табакерка" - сидят спекулянты, шулера, публичные девки и лопают пирожки по сто целковых штука, пьют ханжу из чайников, а поэты и беллетристы (Алешка Толстой, Брюсов и так далее) читают им свои и чужие произведения, выбирая наиболее похабные» (И.А. Бунин. Окаянные дни. 1925) речь шла о литературном кафе «Музыкальная табакерка», открытом имажинистом В.Г. Шершеневичем.

О широте распространения слова в 20-30-е гг. XX в. в общенародном языке свидетельствует и его фиксация словарем Д.Н. Ушакова: «ханжа́, ханжи, мн. нет, ж. (китайск.) (простореч.). 1. Китайская хлебная водка желтого цвета, ханшин. 2. Всякий суррогат алкогольных напитков» [18. C. 732]. По сообщениям корреспондентов периодических изданий 19101920-х гг., употребление денатурированного спирта было свойственно не только жителям городов, но и сельской местности. Например, отравления суррогатом случались в Смоленской губернии («Русское слово». 1910.01.19). Эту территорию распространения подтверждают данные диалектных словарей: в Смоленской области записаны ха́нька 'самогон': «Денег не было, так пили ханьку» и хо́нжа в том же значении: «Рвали хмель, варили с картошкой и добавляли сусла. Затирали хонжу. Гнали ее, как отстоится» [19. Вып. 11. С. 47, 68].

Обобщая данные о географии слова ханжа и его дериватов в русских говорах, отметим, что помимо Дальнего Востока и Сибири слова с основой ханж-, ханш-, хонж-, ханк-, хан- в значении 'спирт, самогон, брага' встречаются на западе России в Смоленской области, на севере - в некоторых районах Вологодской области (Белозерский, Междуреченский, Тарногский, а также пограничные с Костромской областью Великоустюгский, Кичменгскогородецкий и Никольский районы) и повсеместно распространены в Архангельской области, ср. в-уст., к-г., ник. ханжа́ 'сладкое пиво, сваренное с диким хмелем; брага': «Ханжа вышла как мед, такая крепкая» [20. Вып. 11. С. 178], арх. он. ха́ньжа [21. С. 460], арх. в-т. хо́ньжа, арх. в-т., вил., пин., прим., холм. ханьжа́ ‘брага, самогон': «Да вот сильная была, градусов двадцать, как красно вино, ханьжа звали да брага» (арх. холм.); Ханжа-то, бражка-то была заманьчива, но выпьем - руки-ноги отымутся, в голове-то всё ошаровит» (арх. пин.); «Ханжа-то крепкая, долго стоит, дикосьти придает» (арх. вил.) [22. Вып. 3. С. 149; Вып. 10. С. 146, 336; Вып. 11. С. 152; Вып. 16. С. 407; Вып. 18. С. 16]. На Русском Севере ханжой называли самогон, получаемый из остатков от варки пива, а также 
крепкое, перебродившее пиво: «Пиво переживет и хмелеет крепко - дак ханжа» (арх. в-т.); «Отбросы от пива - так ханьжа, если самогонка не получилась - тоё же» (волог. м-реч.) [1].

Значение 'алкоголь' у слов с корнем ханж- обнаружено также в новгородских диалектах, ср. ханжу́ха 'самодельное вино, брага' [23. С. 1242]. Однако в говорах других территорий (помимо Русского Севера, Сибири) ханжа 'брага' встречается намного реже' ${ }^{1}$ Центром распространения ханжи - алкогольного напитка можно считать Приамурье, юго-восточную Сибирь и Русский Север - Архангельскую и Вологодскую области. Тем не менее указанная территория кажется весьма условной: по всей видимости, слово встречалось и шире, но не фиксировалось диалектными словарями, поскольку оценивалось лексикографами как жаргонное или просторечное. Распространению слова ханжа 'самогон' в русском просторечии и говорах способствовали государственные антиалкогольные кампании и государственная монополия на производство спиртных напитков: ханжа и его производные нередко употреблялись как своего рода эвфемизмы, которые скрывали от посторонних и официальных лиц информацию об алкоголе, ср. контексты «Ханжой-то звали, от советской власти скрывались» (арх. котл.) [1].

В Вологодской обл. в значении 'самогон, брага' встречается слово $\boldsymbol{x a}$ нb́rza: «Раньше ведь по деревням ходили. Ханыгу наварим, пива» (волог. ник.); «На свадьбу пива наварили да в Вологду за ханыгой съездили» (волог. шексн.) [Там же]. Думается, его также можно считать родственным прост. ханшин 'китайская водка', образованному в результате ряда фонетико-словообразовательных трансформаций. Форма ханыга могла возникнуть под влиянием распространенного на той же севернорусской территории омонима ханы́za в значении 'попрошайка' (волог. в-уст.), 'ленивый человек, пьяница' (волог. ник.), 'хитрый, ушлый человек’ (волог. ник.) [Там же].

Слово ханыга 'проныра, попрошайка' не имеет надежной этимологии, не рассматривается в этимологических словарях. В статье С.В. Зориной «К этимологии слова ханыга» высказано несколько версий его происхож-

${ }^{1}$ В соседних вятских, новгородских и ярославских диалектах, а также в говорах Поволжья основное значение слов с корнем хан(b)ж-, ханыж- - 'ходить без дела', 'просить, клянчить', 'попрошайка': ср. ханьжа́ 'везде таскающийся без дела' (новг.), 'попрошайка' (вят., новг.) [24. С. 245], яросл. хань́љничать 'нудно и надоедливо просить, клянчить' [25. Вып. 10. С. 30] и мн. др. Эти лексемы гетерогенны по отношению к

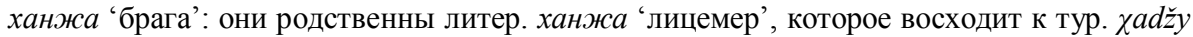
'паломник' (ср. татар. хажси) [26. Т. 4. С. 222]. На севернорусских территориях слово ханжа 'самогон, брага' также оказывается в окружении омонимичных форм, представленных общенар. ханжа и его диалектными вариантами и производными, ср. волог. ник. ханжа́ 'человек с тяжелым характером' [1], костром. вохом. ханьжи́ла 'попрошайка', ханжи́ть 'уезжать, искать новое место для жизни' [2] и др. Народная этимология нередко соотносит омонимичные гнезда ханж-: ср. волог. в-важ. ханжа 'брага': «Ханжа стоит. Надоедает - дай, мама, дай, - от слова выханжит, выпросит значит» [1]. 
дения. Наличие формы вост. новг. ханьжа́ 'то же, что ханыга, попрошайка', 'везде шатающийся без дела' позволяет предположить этимологическую связь слова ханыга с сущ. ханжа 'лицемер' [27. С. 95]. Переход ханжа > ханыга мог произойти под влиянием сущ. на -ыға, ср. забулды́za, тоponbíza, яры́za [Там же]. Поскольку существует словообразовательная возможность возникновения формы ханыга 'попрошайка' из ханжа 'лицемер', стоит предположить и возможность происхождения ханыга 'самогон, брага' от сущ. ханжа в том же значении.

Лексемы ханыга 'проныра, попрошайка' и ханыга 'алкогольный напиток', будучи гетерогенными, могут быть вторично связаны семантической моделью 'проныра; попрошайка' > 'пиво, алкогольный напиток', примеры которой встречаются и в других словообразовательных гнездах. Подобным образом значения 'болтун, обманщик' и 'пиво' соотносятся в выражениях арх. свистуна́ принесли 'о пиве третьего слива' [1] при свисту́н 'врун' (арх. пин.), ‘жулик' (новг.), ‘болтун, обманщик' (свердл.) [8. Вып. 36. С. 301]; костром. вохом. прощельіга 'пиво второго или третьего слива' [2] и костром. прощельіга 'мот, ветреный человек', 'обманщик, лгун, хвастун' [8. Вып. 33. C.57]; волог. бабуш., ник. шату́н 'сладкое пиво; крепкий алкогольный напиток' [1] и шату́н 'беспутный человек' (арх. карг., волог. выт.), 'головокружение' (арх. карг.) [28. Вып. 6. С. 843]. Кроме того, для народной речи весьма характерны примеры, в которых слова гнезда хан'попрошайничать, клянчить' денотативно связаны с темой алкоголя и пьянства, ср.: волог. выт., кад. ханы́zа 'пьяный человек', волог. выт. ханы́чить 'выпрашивать': «Ханыга ходит, ханычит оливину, выпить хочет» [1].

В Никольском районе Вологодской области записана форма шанга́ 'брага, самогон, перебродившее пиво и другие крепкие алкогольные напитки низкого качества': «Шанга - бардама-то это и называется. Дрожжей пустят до воды и пьют шангу-то»; «Шаньга и ханьжа одно слово, старопрежнее»; «Ханыгу делаем да шангу ставим. Стакан-два выпьешь, зашатаешься, конечно»; «Шанга - это пиво, хмельное. Шанга, бодяга - это одно и то же» [Там же]. Учитывая сходство диалектной семантики слов ханжа, ханыга 'самогон, брага' и шанга, их параллельное функционирование на одной узкой территории Никольского района Вологодской области (западная часть района, бассейн р. Кема), стоит предполагать их родство: фонетический переход $x$ - > $u$-, возможно, произошел по аналогии с чередованием начальных $x$-//u- в омонимичных формах ханы́ź, хальі́zа и шаны́іга, шальіza 'попрошайка, бездельник', широко распространенных в русских говорах [27. С. 97] ${ }^{1}$. Примеры чередований $u-/ / x$ - в основах шал- // хал- в русских говорах приводятся также в [29. С. 117], ср. рус. диал. шало-

${ }^{1}$ Как предположительно родственное слову ханыга 'шатун, попрошайка' С.В. Зорина рассматривает диал. хальга, халдыга и шалыга, шанысга 'шатун, шальной, праздный колоброд'; шаньіжничать 'праздно шататься, баклушничать', представляющее чередование $x-/ / m$-, обусловленное переходом праслав. *xēl- $>$ *šal-. Генетическую общность, возможно, представляют дериваты основ хал-, хан-, шал-, шан- в значении 'попрошайка; шататься без дела, попрошайничать' [27. С. 97]. 
ným // холопу́тка, шалобро́дить // халабро́дить, халабу́рда // шалаби́рда, шаромыга // халамыга и др. [Там же].

Чемергес. В Шарьинском р-не Костромской обл. в значении 'плохое, некачественное вино, брага; самогон' употребляется слово чемерге́с: «Самогонку называли чемергес, нагонила, скажут, чемергесу»; «Бражка плохая, чемергес, пить нечего»; «Как чемергес, нисколе нет крепости» [2]. Единично слово записано в Вологодской области: «Чемергес из хлеба делали» (шексн.) [1]. В диалектных словарях лексема практически не представлена. Так, в смоленских говорах встречается чемерге́с 'самогон': «На свадьбу чемергес гнали» [19. Вып. 11. С. 99]; чемерге́с 'очень крепко заваренный чай' зафиксировано в Лодейнопольском районе Ленинградской области: «Чемергес если цельную пачку заварить в самовар» [28. Вып. 6. С. 769]. В просторечии г. Заводоуковска Тюменской области 1970-х гг. встречалась форма чемурде́с 'самогон' (из устной беседы с М.Э. Рут).

В русские говоры слово проникло из городского просторечия или жаргона. Большинство его фиксаций приходится именно на жаргонные словари, ср. угол. чемарге́с, чемерге́ 'самогон', чемерге́с 'дешевое вино низкого качества', 'низкокачественный самогон', нарк. 'чифир, наркотический напиток из чая', угол. чемерге́сник 'самогонщик', чемерге́сница 'самогонщица' [30. С. 667], одес. чемергес 'низкокачественный самогон' [31]. В украинском жаргоне находим формы че́мер и чемерге́с 'самогон': «Ми и без твоєї горілки обійдемось: купим у баби Польки чемергесу» [32. С. 362]. В жаргонный словарь Л. Ставицькой слово попало из изданного ранее словаря говоров Нижнего Приднепровья В.А. Чабаненко, где приводится с тем же контекстом и указанием на территорию - село Малая Токмачка Ореховского района Запорожской области [33. С. 211]. В белорусских говорах Гродненского района записано чэмярге́с 'самогонка' [34. С. 553].

Слово чемергес и его дериваты не часто, но употребляются в русском городском просторечии, встречаются в текстах современной прозы: так называют крепкий спиртной напиток, промышленный концентрат (например, концентрат «Тархуна» крепостью 70\%, который пили рабочие винзавода [35] или технический спирт [36]. У В. Ионова герои чемергеcяm - готовят горячую водку с медом, которая отличается сильным хмельным воздействием [37]. В рассказе М. Вировлянского чемергесом называется напиток на основе денатурированного спирта, который готовили рабочие литейного цеха: для автора он стал символом тяжелой и беспросветной жизни заводчан [38]. Некоторым авторам чемергес представляется вполне положительным символом российской жизни, незатейливого и душевного отдыха с друзьями, ср. слова из песни «Чемергес» саратовца В. Узембло: «Чемергес хлебаешь - // Отдыхаешь головой <...> А Виталя с Риммой чемергеса наварили < ..> Трава-трава - самогоночка, // Траватрава - чемергес, // Трава-трава - потихонечку, // Трава-трава - до небес» [39]. Помимо алкогольного напитка, название чемергес относится к острому томатному соусу наподобие аджики (см., например, [36]): это значение, вероятно, производно от “крепкий, “обжигающий алкоголь”. 
Происхождение сущ. чемергес остается загадочным прежде всего в силу нетипичной словообразовательной модели. Предположительно слово связано с названием села Чемер Черниговской губернии, где помещиками Пашковыми в 1912 г. был открыт спиртовой завод, который просуществовал все советские годы и работает до сих пор: именно водку этого завода стали называть чемергес [40]. Появление конечного -гес можно объяснить тем, что название чемергес возникло как просторечное сокращение от *Чемерский государственный спиртовой завод (Чемер-гэ-сз), которое было перенесено с названия завода на выпускаемую им продукцию. Употребление слова чемергес в русском, белорусском и украинском языках, очевидно, было обусловлено тем, что на территории этих стран еще с советского времени ввозили большие объемы нелегального спирта, произведенного на Чемерском заводе. Продажам чемерского спирта способствовало северо-восточное расположение Черниговской области, близкое к территориям России и Белоруссии.

Можно также предположить, что слово чемергес родственно лексемам гнезда чемер- (праслав. *čетеr-), которые широко распространены в русских говорах и других славянских языках как обозначения ядовитого растения чемерицы, отравы, яда, различных болезней человека и скота, ср. рус. чемери́иа, блр. чэмер, чамярь́й, укр. чемериия 'чемерица', рус. вят. че́мер 'яд и боль от яда', рус. нижегор. че́мерь 'головокружение и боль в животе у человека' [41. Вып. 4. С. 52-54]. В народной традиции (кстати, именно украинской) настойка чемерицы могла употребляться как алкоголь или лекарственное средство, ср. укр. чемерівка 'настойка на чемерице': «Будем пити мед-горівку, а потому чемерівку» [42. Т. 4. С. 451]. Ряд контекстов указывает на то, что и в состав чемергеса входил экстракт чемерицы, отмечается его дурманящий эффект и тяжелое влияние на организм ${ }^{1}$. Однако тот факт, что в состав чемергеса входил экстракт чемерицы, кажется весьма сомнительным, поскольку при приеме внутрь чемерица оказывает токсическое действие на организм. Существует официальное лекарственное средство чемеричная вода, которое используется исключительно наружно. Тем не менее в народной медицине настой чемерицы применяют «внутрь» при борьбе с алкоголизмом - несколько капель, добавленные в

${ }^{1}$ Существуют и другие примеры мотивационной связи обозначений алкогольных напитков низкого качества с названиями яда, отравы, ср. сулемá 'невкусный алкогольный напиток’ (костром. пав.): «Напоили какой-то сулемой, дак и во рту небаско так, раньше бражку делали дак чего» [2], 'брага' (волог. сямж.), 'бурда, бормотуха' (арх. лен.): «Вчера такую сулему принесли, горькую, всю ночь отрыгалось», ‘бутылка спиртного напитка "Бальзам”" (волог. хар.): «Раньше бальзан вино было, красные бутылки, их сулема звали», 'приворотное зелье' (арх. уст.), 'о чем-л. невкусном, неприятном' (волог. бел., кад.): «Сулемы всякой наешься, вот и плохо потом» (волог. кад.) [1], 'всякий яд, отрава' (волог., вят.), 'что-л. горькое, горечь' (арх. вель.) [8. Вып. 42. С. 219-220], которое восходит к химическому термину сулема 'хлорид ртути'. В медицинской практике XIX в. раствор сулемы использовали для лечения некоторых заболеваний, однако, как отмечает В.И. Даль, сулемовый настой, которым пользовались крестьяне, часто приводил к отравлениям [43. Т. 4. С. 359]. 
алкогольный напиток, вызывают у пьющего тошноту и другие неприятные симптомы. Кроме того, версия о родстве сущ. чемергес с гнездом чемер-, даже семантически обоснованная, не объясняет «замысловатой» формы слова - происхождения финали -гес. Наиболее вероятным стоит считать первое предположение - о связи сущ. чемергес с жаргонным сокращением названия Чемерский государственный спиртовой завод. Единственное, что не дает быть окончательно уверенным в этой версии, - это отсутствие в наших материалах фиксации аббревиатуры Чемергес в качестве обозначения Чемерского спиртового завода в живой речи, а также вторичное сближение слова чемергес с гнездом чемер-.

Примечательно, что в некоторых костромских говорах чемергес как более современная и экспрессивная форма вытеснила архаичные лексемы гнезда чемер-, ср. костром. шар. чемерге́с 'неаккуратный, неопрятный человек', ‘неопрятный, шаловливый ребенок', 'неумелый человек', 'смуглый человек', 'бранное обращение’ [2]. На этой же территории записан гл. чемерге́сить 'делать плохо, некачественно', 'бормотать, говорить (о пьяном человеке)': «Напьются, так все чемергесят - бароешат, мелют ладно и неладно» [Там же], в значениях которого прослеживаются мотивы пьянства, негативно оцениваемого поведения, толчком к развитию которых стало проникновение в костромские говоры жаргонного слова чемергес 'самогон'.

Наименования алкогольных напитков, восходящие к имени собственному - названию завода-производителя, места производства или продажи, далеко не единичны. Подобные названия фиксировались диалектными источниками еще с XIX в. - например, водка крохалевка (арх. карг.) изготавливалась на заводе купца Крохалева в городе Каргополе [8. Вып. 15. С. 286]. Ярославское название домша́рик 'самогонка, водка, разбавленная чаем и подслащенная', записанное в Пошехонском районе, отсылает к названию деревни Домшино Шекснинского района Вологодской области [Там же. Вып. 8. С. 122]. Известно, что в конце XIX - начале XX в. в вологодском селе Домшино проходили крупные ярмарки [44]. Скорее всего, их посещали и жители приграничного Пошехонского района Ярославской области, а водка с чаем и сахаром была типичным ярмарочным угощением.

Сучок. В Вельском районе Архангельской области записаны слово $c y$ чóк 'некачественная водка из гидролизного спирта' и выражение вологодский сучок: «Понимающие питухи говорят, что хуже хлебной, дерет, как сучок» [8. Вып. 43. С. 36]. Слово пришло в севернорусские говоры в советское время из городского просторечия и жаргона - так повсеместно назывался этиловый спирт, производимый из целлюлозы на гидролизных заводах, а вместе с ним и некачественный алкоголь, ср. жарг. сучо́к 'водка', 'некачественная водка, самогон' [30. С. 576]. По всей вероятности, именно специфика сырья и отразилась во внутренней форме наименования: сущ. сучок можно сопоставить с другим архангельским обозначением древесного спирта и водки - деревянное вино, которое противопоставляло прежнюю «Хлебную» и новую «деревянную» водку, ср.: «Раньше вино-то было хлеб- 
ное, а сейчас деревянное» (арх. вин.) [22. Вып. 11. С. 68]. Существуют и иные версии происхождения названия сучок ${ }^{1}$. Например, В.В. Похлебкин полагал, что слово связано с особенностями фильтрации спирта«полугара»: «Полугар “с сучками” считался очищенным, а "без сучков" плохим. В настоящее время "сучком" называют всякую низкокачественную водку, хотя следовало бы называть ее как раз наоборот - "без сучка", то есть без фильтрации» (цит. по: [46. С. 346]). При всей аргументированности эта версия не объясняет семантического развития слова сучок: каким образом значение 'фильтрованный алкоголь высокого качества' трансформировалось в 'некачественный, нефильтрованный', а затем и 'изготовленный из древесного спирта'? Кроме того, сама форма сучок 'вид спирта' (а не предложно-падежные варианты с сучками и без сучков) появляется именно в XX в., когда было внедрено гидролизное производство.

Распространение наименований «древесного» этилового спирта на Русском Севере связано с открытием здесь нескольких гидролизных заводов: в 1934 г. был пущен Череповецкий опытный завод, в 1941 г. - Архангельский гидролизный завод, в 1954 г. - Онежский гидролизный завод. Древесное сырье на Русском Севере всегда было в достатке, и вставала проблема химической переработки отходов деревообрабатывающих предприятий, кроме того, запуск гидролизного производства был обусловлен необходимостью в экономии хлеба, в том числе в военное время.

Чача. Еще одно название, заимствованное в севернорусские говоры в советский период, - ча́ча 'домашнее вино или пиво; вино, продаваемое из бочек’ (арх. карг., волог. нюкс., костром. вохом.): «Чачей раньше называли пиво, возили в бочках продавали, вот чачу привезли», 'разливное красное вино’: «Разливное красное вино раньше чачей звали, в бочках его возили, обычное вино, но разливное - чача», 'самогон, брага': «На дрожжах настоят песок - вот это и чача» (костром. вохом.) [2]; «Чачи подвыпил» (арх. карг.); «Вино красное в бочках мужики чачей называли» (волог. нюкс.) [1]. Вполне возможно, что слово появилось в костромских говорах в XX в. вместе со спорадической продажей на территории СССР вин и других спиртных напитков из Грузии, в том числе грузинского самогона-чачи. Судя по приведенным контекстам, торговали спиртным приезжавшие в деревни автолавки.

${ }^{1}$ Приведем еще одно предположение о происхождении названия сучок: «В народе распространена и более логичная версия: это жаргонное название дешевой водки происходит от внешнего вида горлышка бутылки, запечатанной коричневым (в отличие от более дорогой “белой головки”) сургучом (в действительности и по официальным документам - “смолкой”), что делало горлышко бутылки похожим на срезанный и соответственно обработанный сучок плодового дерева. Именно так закупоривалась водка вплоть до 50 -х годов < .. > Наиболее правдоподобной выглядит версия крупнейшего коллекционера водочных этикеток и прочих сопутствующих материалов В.Е. Крылова < .. > Нормативные акты 30-х годов регламентировали закупорку бутылок водки корковой пробкой, которая при ударе по донышку выбивалась как сучок и имела вид такового. На практике допускалось использование деревянной пробки. Отсюда и название» [45]. 
Брындахлест. Заимствование в русский язык иноязычных лексем, обозначающих спиртные напитки, как и в предыдущем случае с костром. чача 'пиво, самогон', обычно сопровождается сдвигом или расширением значения. Так, например, развивалась и семантика прост. брандахльі́ст, представленная в говорах формами волог., твер. брындахле́ст 'жидкое пиво; дурное, безвкусное и жидкое хмельное питье; рассыропленная, слабая или горелая сивуха' [43. Т. 1. С. 123], ворон., перм. брандахльі́ст 'водка, самогонка' [8. Вып. 3. С. 148]. Согласно одной из существующих этимологий, это слово образовано путем словосложения, в котором вторая часть «связана с прост. хлыста́mь (наряду с хлеста́mь) 'хлестать', 'пить водку и т. п. в больших количествах' <..> Перв. часть нередко понимают как нар. переделку польск. brand-/t- в brandebuła, brandziucha, brantucha 'водка' от TO Brandenburg, см. Бранденбург. Польск. слова сопоставляют также с нем. Branntwein 'водка', см. бре́нди» [15. Т. 4 (2). С. 154]. Таким образом, слово, обозначающее водку в языке-источнике, в русском просторечии и народных говорах используется в значении 'водка, самогонка' и 'некачественный алкогольный напиток'.

Пунш, пунч. В Онежском районе Архангельской области, а также в некоторых районах Карелии (Кемский район), Ленинградской (Подпорожский, Тихвинский районы) и Мурманской области (Кандалакшский и Терский районы) записано сущ. пунч, пунш 'водка, разведенная кипятком; чай с водкой' [28. Вып. 5. С. 348]. География этого слова ограничена районами, расположенными на побережье Белого моря и прилегающими к ним территориями. Вероятно, что сущ. пунш было заимствовано жителями Русского Севера в начале XX в. из речи английских военных-моряков, которые с 1914 по 1919 г. оказывали помощь царскому правительству, а затем белому движению: грузовые и военные суда союзников прибывали преимущественно в порты Архангельска и Мурманска. Таким образом, непосредственным источником рус. диал. пунш можно считать англ. punch 'спиртной напиток из рома (виски, коньяка и др.), разбавленного водой и сваренного с сахаром, лимонным соком или фруктами’.

Ракеж. Волжским путем с юга России на территорию костромского Поветлужья пришло слово раке́ж 'самогон', раке́жить 'варить самогон, пить самогон' [8]. В южных говорах русского языка записаны, например, новорос. раки́й 'водка' [Там же], краснодар., кубан., ставроп., терек. ра́ка́ 'самогон, водка' [Там же], усвоенные из тур. rakl 'водка' [15. Вып. 1. С. $255 ; 26$. Т. 3. С. 438], т.е. из того же источника, что болг. раки́я, с.-хорв. rakija 'водка из фруктов, ракия' [15. Вып. 1. С. 255]. Притом что костром. раке́ж восходит к турецкому источнику, его оформление А.Е. Аникин считает не до конца ясным.

$* * * *$

Названия крепких алкогольных напитков интересны с точки зрения установления контактов города и деревни и путей заимствования новых 
лексем в говоры. Эта лексическая группа в значительной степени формировалась «извне» - путем заимствования новых слов из просторечия и жаргона, нежели «изнутри» - путем метафоры или иных механизмов развития значений. Хронологически контакты можно отнести как к XIX в., когда в севернорусские говоры попали слова брандахлест, ракеж, так и к $\mathrm{XX}$ в., когда в диалекте появились наименования сучок, ханжа, чача, чемергес и др.

На интенсивность расширения лексической группы существенно повлияли внеязыковые социально-экономические факторы. Она пополнялась во время всякого более или менее весомого изменения в законодательстве, регулирующего производство и продажу спиртных напитков: во времена «сухого закона» и антиалкогольных кампаний появляются наименования нелегально произведенного или контрабандного алкоголя, с отменой «сухого закона» в язык входят названия новых спиртных напитков. Так, объявленный царским правительством в 1914 г. «сухой закон» был поддержан советской властью: первые послабления произошли в 1919 г., а полностью он был отменен только в 1923-1925 гг. постановлением ЦИК СССР и СНК СССР, председателем которого был А.И. Рыков. В это время было запущено производство водки крепостью $30^{\circ}$, которая получила неофициальное название рыковка и полурыковка. Это название бытовало не только в городском просторечии, например, оно было записано в ярославских говорах (1908-1928 гг.), ср. ры́ковка 'горькое вино, водка': «Приезжай же сват к нам в гости и то, я и рыковки куплю» [8. Вып. 35. С. 307]. На Русском Севере распространению крепкого и суррогатного алкоголя способствовало открытие в 30-50-е гг. гидролизно-спиртовых заводов, специализирующихся на переработке остатков древесины.

Многие наименования, возникшие в антиалкогольную эпоху, воспринимались как конспиративные, которые скрывали тему алкоголя от посторонних и официальной власти. К таким обозначениям можно отнести, помимо упомянутых сучок, ханжа, ханыга и др., например, костромские названия самогона кисленькая водичка или дымная водичка (окт.), ржаное масло (окт.): «Ходят, всё ишшут ржаного-то масла», го́бцешная (мант.), го́лбешная: «Нагонят самогонку да уберут в голбце, а он у матери украдет, придет да говорит, давай голбешную пить» (шар.) [2].

\section{Сокращения в названиях районов}

бабуш. - Бабушкинский район Вологодской области бел. - Белозерский район Вологодской области в-важ. - Верховажский район Вологодской области вель. - Вельский район Архангельской области вил. - Вилегодский район Архангельской области вин. - Виноградовский район Архангельской области вохом. - Вохомский район Костромской области в-т. - Верхнетоемский район Архангельской области в-уст. - Великоустюгский район Вологодской области выт. - Вытегорский район Вологодской области 
кад. - Кадуйский район Вологодской области

карг. - Каргопольский район Архангельской области

к-г. - Кичменгско-Городецкий район Вологодской области

котл. - Котласский район Архангельской области

лен. - Ленский район Архангельской области

мант. - Мантуровский район Костромской области

м-реч. - Междуреченский район Вологодской области

ник. - Никольский район Вологодской области

нюкс. - Нюксенский район Вологодской области

окт. - Октябрьский район Костромской области

он. - Онежский район Архангельской области

пав. - Павинский район Костромской области

пин. - Пинежский район Архангельской области

прим. - Приморский район Костромской области

сямж. - Сямженский район Вологодской области

уст. - Устьянский район Архангельской области

холм. - Холмогорский район Архангельской области

шар. - Шарьинский район Костромской области

шексн. - Шекснинский район Вологодской области

\section{Лumepamypa}

1. Картотека «Словаря говоров Русского Севера» (кафедра русского языка, общего языкознания и речевой коммуникации Уральского федерального университета, Екатеринбург).

2. Лексическая картотека Топонимической экспедиции Уральского федерального университета (кафедра русского языка, общего языкознания и речевой коммуникации Уральского федерального университета, Екатеринбург).

3. Андреева Т.Б. Пиво как праздничный напиток жителей Русского Севера (XIX начало XX века) // Праздничная и обрядовая пища народов мира / отв. ред. С.А. Арутюнов, Т.А. Воронина; Ин-т этнологии и антропологии им. Н.Н. МиклухоМаклая РАН. М., 2017. С. 134-158.

4. Андреева Т.Б. Традиции сельского пивоварения на Русском Севере в XIX - начале XXI в. : автореф. дис. ... канд. ист. наук / Институт этнологии и антропологии им. Н.Н. Миклухо-Маклая РАН. М., 2006. 25 с.

5. Воронина T.A. Пивоварение и связанные с ним традиции праздничного застолья в Вологодской губернии в конце XIX века (по материалам Этнографического бюро князя В.Н. Тенишева) // Важский край: Источниковедение, история, культура. Вельск, 2002. C. $68-83$.

6. Осипова К.В. Лексика пивоварения на Русском Севере: этнолингвистический аспект // Вестник Томского государственного университета. Филология. 2017. № 48. C. $57-73$.

7. Осипова К.В. Традиции употребления пива на Русском Севере: этнолингвистический аспект // Славянский альманах. 2017. № 3-4. С. 463-478.

8. Словарь русских народных говоров / под ред. Ф.П. Филина (вып. 1-22), Ф.П. Сороколетова (вып. 23-42), С.А. Мызникова (вып. 43-48). М. ; Л. ; СПб. : Наука, 1965-2015. Вып. 1-48.

9. Аникин А.Е. Этимологический словарь русских диалектов Сибири: Заимствования из уральских, алтайских и палеоазиатских языков. 2-е изд., испр. и доп. Москва ; Новосибирск : Наука, 2000. 772 с.

10. Национальный корпус русского языка. URL: http://www.ruscorpora.ru/index.html (дата обращения: 05.03.2018). 
11. Оллезнева Е.А. Дальневосточный региолект русского языка: особенности формирования // Русский язык в научном освещении. 2008. № 2 (16). С. 119-136.

12. Словарь русских говоров Приамурья. М. : Наука. 1983. 341 с.

13. Словарь русских говоров Сибири / под ред. А.И. Федорова. Новосибирск : Наука, 1999-2006. Т. 1-5.

14. Вершининский словарь / гл. ред. О.И. Блинова. Томск : Изд-во Том. ун-та, 19982002. T. 1-7.

15. Аникин A.E. Русский этимологический словарь / Ин-т рус. яз. им. В.В. Виноградова РАН, Ин-т филологии Сибирского отделения РАН. М. ; СПб., 2007-2017. Вып. 111.

16. Аксенов В.Б. «Сухой закон» 1914 г.: от придворной интриги до революции // Российская история. 2011. № 4. С. 126-139.

17. Арзамас: История, литература, искусство в лекциях, шпаргалках, играх и ответах экспертов: новые знания каждый день. URL: https://arzamas.academy (дата обращения: 05.03.2018).

18. Ушаков Д.Н. Толковый словарь современного русского языка. М. : Аделант, 2014. $800 \mathrm{c}$.

19. Словарь смоленских говоров / отв. ред. Л.З. Бояринова, А.И. Иванова. Смоленск : Изд-во СГПИ-СГПУ, 1974-2005. Вып. 1-11.

20. Словарь вологодских говоров. Вологда : ВГПУ : Русь, 1983-2007. Вып. 1-12.

21. Мызников С.А. Русские говоры Беломорья: материалы для словаря. СПб. : Наука, 2010. 496 с.

22. Архангельский областной словарь / под ред. О.Г. Гецовой. М. : Изд-во МГУ, 1980-2017. Вып. 1-18.

23. Новгородский областной словарь / изд. подгот. А.Н. Левичкин, С.А. Мызников. СПб. : Наука, 2010. 1435 с.

24. Onыm областного великорусского словаря, изданный Вторым отделением Императорской академии наук. СПб., 1852.300 с.

25. Ярославский областной словарь / отв. ред. Г.Г. Мельниченко. Ярославль : ЯГПИ им. К.Д. Ушинского, 1981-1991. Вып. 1-10.

26. Фасмер М. Этимологический словарь русского языка. М. : Прогресс, 1964-1973. T. $1-4$.

27. Зорина С.В. К этимологии слова ХАНЫГА // Этимологические исследования : сб. науч. тр. Свердловск, 1984. Вып. 3. С. 94-98.

28. Словарь русских говоров Карелии и сопредельных областей / гл. ред. А.С. Герд. СПб. : Изд-во СПб. ун-та, 1994-2005. Вып. 1-6.

29. Сурикова О.Д. Еще раз о русском слове шаромыга // Научный диалог. 2016. Вып. 10 (58). С. 113-124.

30. Мокиенко В.М., Никитина Т.Г. Большой словарь русского жаргона. СПб. : Норинт, $2000.717 \mathrm{c}$.

31. Котов-Померанченко В. Язык Одессы: Слова и фразы. Одесса : Optimum, 2013. $167 \mathrm{c}$.

32. Ставицька Л. Український жаргон. Словник. Київ : Критика, 2005. 496 с.

33. Чабаненко B.A. Словник говірок Нижньої Наддніпрянщини. Запоріжжя : ЗДУ, 1992. Т. 4: Р-Я.

34. Сияшковіч T. Ф. Матэрыялы да слоўніка Гродзенскай вобласці. Мінск : Навука і тэхніка, $1972.618 \mathrm{c}$.

35. Форум выпускников ЕВВАУЛ (архивный). URL: http://forum.a.evvaul.com/ index.php?topic $=661.460$ (дата обращения: 05.03.2018).

36. Калий $O$ Аш. Неожиданно. URL: https://www.liveinternet.ru/users/ 1045060/post403558493 (дата обращения: 05.03.2018).

37. Ионов B. Tot-Svet@mail.ru // Электронная библиотека. ModernLib.Ru. URL: http://modernlib.ru/books/vladimir_ionov/tot-svetmailru/read (дата обращения: 05.03.2018). 
38. Вировлянский М. Чемергес// Проза. py. URL: http://www.proza.ru/2012/12/26/833 (дата обращения: 05.03.2018).

39. Официальный сайт группы «Незваный гость». URL: http://negost.ru (дата обращения: 05.03.2018).

40. Коиюра И. Два Алексея из Чемера, или Что такое «чемергес»? // Взгляд. № 42 (176). URL: http://www.gorod.cn.ua/news/gorod-i-region/21078-dva-alekseja-iz-chemera-ilichto-takoe-chemerges.html (дата обращения: 05.03.2018).

41. Этимологический словарь славянских языков / под ред. О.Н. Трубачева (вып. 131), А.Ф. Журавлева (вып. 32-40). М. : Наука, 1975-2016. Вып. 1-40.

42. Гринченко Б.Д. Словарь украинского языка. Киев : 1907-1909. Т. 1-4.

43. Даль В.И. Толковый словарь живого великорусского языка. М. : Гос. изд-во иностр. и нац. слов., 1955. Т. $1-4$.

44. Глебова А.А. Домшинская береста // Научные чтения памяти В.М. Василенко. Вологда, 2003. С. 42-49.

45. Крылов А. Не квасом земля полита: Примечания к «человеческой трагедии» Александра Галича // Независимый альманах Лебедь. 25.06.2000. URL: http://lebed.com/2000/art2197.htm (дата обращения: 05.03.2018).

46. О вине и пьянстве: Русские пословицы и поговорки / сост., предисл., словарь, примеч. Г.Ю. Багриновского. М. : Аграф, 2001. 480 с.

\section{NAMES OF STRONG ALCOHOLIC DRINKS IN THE RUSSIAN NORTH: ETYMO- LOGICAL AND ETHNOLINGUISTIC ANALYSIS}

Vestnik Tomskogo gosudarstvennogo universiteta. Filologiya - Tomsk State University Journal of Philology. 2018. 56. 146-165. DOI: 10.17223/19986645/56/8

Ksenia $V$. Osipova, Ural Federal University (Yekaterinburg, Russian Federation). E-mail: osipova.ks.v@yandex.ru

Keywords: Russian language, dialectology, jargon, popular language, Russian North, drinks, alcohol, etymology, ethnolinguistics.

The article deals with names of strong alcoholic drinks found in the territory of the Russian North. The material of the article includes data from the dialects of the Arkhangelsk and Vologda Regions, as well as the northeast of the Kostroma Region (northern part of the Sharya District, Vokhomsky, Oktyabrsky, Pavinsky Districts, formerly belonging to the Vologda Region). The main sources of the material were the lexicographic files of the Ural Federal University Toponymic Expedition. The work aims to carry out an etymological and ethnolinguistic interpretation of the dialect vocabulary of the Russian North that nominates strong alcoholic drinks. The author examines the ways of strong alcoholic drinks names creation in the Northern Russian dialects, determines the area of their distribution and genetic links. Such methods as semantic-motivational, geographic-linguistic analysis, comparative analysis of the vocabulary of various forms of the language are used to build a complex ethnolinguistic research.

The article analyzes the lexemes of Arkhangelsk, Vologda hanzha, Vologda, Kostroma chemerges, Arkhangelsk suchok, Arkhangelsk, Vologda, Kostroma chacha, Arkhangelsk punsh, Kostroma rakezh and others: for each of them the author defines the dialects, in which these lexemes function and a version of the origin. Historical and cultural commentaries are also given. During the study it was established that most of these words are borrowed from the common language or jargon. So, Arkhangelsk, Vologda hanzha, shanga, hanyga 'alcoholic drink' are regarded as related to the jargon word hanzha 'Chinese raw vodka, surrogate alcohol', borrowed from the Chinese language. Vologda, Kostroma chemerges 'bad, lowquality wine, braga; moonshine', as well as the jargon chemerges, are associated with the slang term reduction of the Chemer State Alcohol Factory.

The author concludes that the intensity of the lexical expansion of the alcoholic drinks group was seriously influenced by extra-linguistic socio-economic factors. These factors were 
becoming more numerous during any change in the legislation regulating the production and sale of alcoholic drinks. During the "dry law" and anti-alcohol companies, names of illegally produced or smuggled alcohol appear; with the abrogation of the "dry law", the language includes the names of new alcoholic drinks. In the Russian North, the spread of strong and surrogate alcohol was incited by the discovery of hydrolytic alcohol distilleries in the 1930s1950s. Many names that appeared in the anti-alcoholic period are perceived as conspiratorial: they were meant to conceal the talks about alcohol from outsiders and official authorities, for example dymnaya vodichka, rzhanoye maslo, golbeshnaya, etc.

\section{References}

1. Department of Russian, General Linguistics and Speech Communication of the Ural Federal University. (n.d.) The Card File of The Dictionary of the Dialects of the Russian North. Yekaterinburg. (In Russian).

2. Department of Russian, General Linguistics and Speech Communication of the Ural Federal University. (n.d.) The Lexical Card File of the Toponymic Expedition of the Ural Federal University. Yekaterinburg. (In Russian).

3. Andreeva, T.B. (2017) Pivo kak prazdnichnyy napitok zhiteley Russkogo Severa (XIX - nachalo XX veka) [Beer as a festive drink of the inhabitants of the Russian North (19th - early 20th centuries)]. In: Arutyunov, S.A. \& Voronina, T.A. (eds) Prazdnichnaya $i$ obryadovaya pishcha narodov mira [Festive and ceremonial food of the peoples of the world]. Moscow: Nauka. pp. 134-158.

4. Andreeva, T.B. (2006) Traditsii sel'skogo pivovareniya na Russkom Severe v XIX-nachale XXI v. [Traditions of rural brewing in the Russian North in the 19th - early 21 st centuries]. Abstract of History Cand. Dis. Moscow.

5. Voronina, T.A. (2002) Pivovarenie i svyazannye s nim traditsii prazdnichnogo zastol'ya v Vologodskoy gubernii v kontse XIX veka (po materialam Etnograficheskogo byuro knyazya V.N. Tenisheva) [Brewing and related traditions of a festive feast in the Vologda province at the end of the 19th century (according to the materials of the Ethnographic Bureau of Prince V.N. Tenishev)]. In: Vasil'ev, Yu.S.Vazhskiy kray: istochnikovedenie, istoriya, kul'tura [Vazhsky region: source study, history, culture]. Vel'sk: Vel'skiy kraevedcheskiy muzey.

6. Osipova, K.V. (2017) Brewing vocabulary in the Russian North: an ethnolinguistic aspect. Vestnik Tomskogo gosudarstvennogo universiteta. Filologiya - Tomsk State University Journal of Philology. 48. pp. 57-73. (In Russian). DOI: 10.17223/19986645/48/4

7. Osipova, K.V. (2017) Traditions of drinking beer in the Russian North: an ethnolinguistic aspect. Slavyanskiy al'manakh - Slavic Almanac. 3-4. pp. 463-478.

8. Filin, F.P., Sorokoletov, F.P \& Myznikov, S.A. (eds) (1965-2015) Slovar' russkikh narodnykh govorov [Dictionary of Russian folk dialects]. Is. 1-48. Moscow; Leningrad; St. Petersburg: Nauka.

9. Anikin, A.E. (2000) Etimologicheskiy slovar' russkikh dialektov Sibiri: Zaimstvovaniya iz ural'skikh, altayskikh i paleoaziatskikh yazykov [Etymological dictionary of Russian dialects of Siberia: Borrowings from the Ural, Altai and Paleo-Asiatic languages]. 2nd ed. Moscow; Novosibirsk: Nauka.

10. Russian National Corpus. [Online] Available from: http://www.ruscorpora.ru/index.html. (Accessed: 05.03.2018). (In Russian).

11. Oglezneva, E.A. (2008) Dal'nevostochnyy regiolekt russkogo yazyka: osobennosti formirovaniya [The Far Eastern Regiolect of the Russian Language: Features of Formation]. Russkiy yazyk v nauchnom osveshchenii - Russian Language and Linguistic Theory. 2 (16). pp. 119-136.

12. Filin, F.P. (ed.) (1983) Slovar' russkikh govorov Priamur'ya [Dictionary of Russian dialects of the Amur region]. Moscow: Nauka.

13. Fedorov, A.I. (ed.) (1999-2006) Slovar' russkikh govorov Sibiri [Dictionary of Russian dialects of Siberia]. Vols 1-5. Novosibirsk: Nauka. 
14. Blinova, O.I. (ed.) (1998-2002) Vershininskiy slovar' [Vershininsky dictionary]. Vols 1-7. Tomsk: Tomsk State University.

15. Anikin, A.E. (2007-2017) Russkiy etimologicheskiy slovar' [Russian Etymological Dictionary]. Is. 1-11. Moscow; St. Petersburg: Nestor-Istoriya.

16. Aksenov, V.B. (2011) The dry law of 1914: from the court intrigue to the revolution. Rossiyskaya istoriya. 4. pp. 126-139. (In Russian).

17. Arzamas. (n.d.) Arzamas: Istoriya, literatura, iskusstvo v lektsiyakh, shpargalkakh, igrakh i otvetakh ekspertov: novye znaniya kazhdyy den' [Arzamas: History, literature, art in lectures, cheat sheets, games and expert answers: new knowledge every day]. [Online] Available from: https://arzamas.academy. (Accessed: 05.03.2018).

18. Ushakov, D.N. (2014) Tolkovyy slovar' sovremennogo russkogo yazyka [Explanatory dictionary of modern Russian]. Moscow: Adelant.

19. Boyarinova, L.Z. \& Ivanova, A.I. (eds) (1974-2005) Slovar'smolenskikh govorov [Dictionary of Smolensk dialects]. Is. 1-11.Smolensk:Smolensk State Pedagogical Institute/University.

20. Zorina, L.Yu. et al. (1983-2007) Slovar'vologodskikh govorov [Dictionary of Vologda dialects]. Is. 1-12. Vologda: Vologda State Pedagogical University: Rus'.

21. Myznikov, S.A. (2010) Russkie govory Belomor'ya: materialy dlya slovarya [Russian dialects of the White Sea: materials for the dictionary]. St. Petersburg: Nauka.

22. Getsova, O.G. (ed.) (1980-2017) Arkhangel'skiy oblastnoy slovar' [Arkhangelsk regional dictionary]. Is. 1-18. Moscow: Moscow State University.

23. Levichkin, A.N. \& Myznikov,S.A. (2010) Novgorodskiy oblastnoy slovar' [Novgorod regional dictionary]. St. Petersburg: Nauka.

24. Second Division of the Imperial Academy of Sciences. (1852) Opyt oblastnogo velikorusskogo slovarya, izdannyy Vtorym otdeleniem Imperatorskoy akademii nauk [Experience of the Great Russian Regional Dictionary, published by the Second Division of the Imperial Academy of Sciences]. St. Petersburg: v tip. Imp.AN.

25. Mel'nichenko, G.G. (ed.) (1981-1991) Yaroslavskiy oblastnoy slovar' [Yaroslavl regional dictionary]. Is. 1-10. Yaroslavl: YaroslavlState Pedagogical Institute.

26. Vasmer, M. (1964-1973) Etimologicheskiy slovar' russkogo yazyka [Etymological dictionary of the Russian language]. Vols 1-4. Moscow: Progress.

27. Zorina, S.V. (1984) K etimologii slova KHANYGA [On the etymology of the word KHANYGA]. In: Etimologicheskie issledovaniya [Etymological research]. Is. 3. Sverdlovsk: Sred.-Ural. kn. izd-vo. pp. 94-98.

28. Gerd, A.S. (ed.) (1994-2005) Slovar' russkikh govorov Karelii i sopredel'nykh oblastey [Dictionary of Russian dialects of Karelia and adjacent areas]. Is. 1-6. St. Petersburg: St. Petersburg State University.

29. Surikova, O.D. (2016) One More Time on Russian Word "Sharomyga". Nauchnyy dialog. 10 (58). pp. 113-124.

30. Mokienko, V.M. \& Nikitina, T.G. (2000) Bol'shoy slovar' russkogo zhargona [Big dictionary of Russian jargon]. St. Petersburg: Norint.

31. Kotov-Pomeranchenko, V. (2005) Yazyk Odessy: Slova i frazy [Language of Odessa: Words and phrases]. Odessa: Optimum.

32. Stavits'ka, L. (2005) Ukraïns'kiy zhargon. Slovnik [Ukrainian jargon. Glossary]. Kiev: Kritika.

33. Chabanenko, V.A. (1992) Slovnik govirok Nizhn'oï Naddnipryanshchini [Dictionary of dialects of the Lower Dnieper region]. Vol. 4. Zaporizhia: ZDU.

34. Stsyashkovich, T.F. (1972) Materyyaly da sloy̆nika Grodzenskay voblastsi [Materials for the Grodno region dictionary]. Minsk: Navuka i tekhnika.

35. Forum.a.evvaul.com. (n.d.) Forum vypusknikov EVVAUL (arkhivnyy) [EVVAUL Alumni Forum (archival)]. [Online] Available from: http://forum.a.evvaul.com/ index.php?topic $=661.460$. (Accessed: 05.03.2018). 
36. Kaliy O Ash. (2016) Neozhidanno [Suddenly]. [Online] Available from: https://www.liveinternet.ru/users/1045060/post403558493. (Accessed: 05.03.2018).

37. Ionov, V. (n.d.) Tot-Svet@mail.ru. [Online] Available from: http://modernlib.ru/ books/vladimir_ionov/tot-svetmailru/read. (Accessed: 05.03.2018). (In Russian).

38. Virovlyanskiy, M. (2012) Chemerges. [Online] Available from: http://www.proza.ru/2012/12/26/833. (Accessed: 05.03.2018). (In Russian).

39. Negost.ru. (n.d.) Ofitsial'nyy sayt gruppy "Nezvanyy gost"” [The official site of the group Nezvanyy Gost']. [Online] Available from: http://negost.ru. (Accessed: 05.03.2018).

40. Kotsyura, I. (2010) Dva Alekseya iz Chemera, ili Chto takoe "chemerges"? [Two Alexeis from Chemer, or What is "Chemerges"?]. Vzglyad. 42 (176). [Online] Available from: http://www.gorod.cn.ua/news/gorod-i-region/21078-dva-alekseja-iz-chemera-ili-chtotakoe-chemerges.html. (Accessed: 05.03.2018).

41. Trubachev, O.N. \& Zhuravlev, A.F. (eds) (1975-2016) Etimologicheskiy slovar'slavyanskikh yazykov [Etymological dictionary of Slavic languages]. Is. 1-40. Moscow: Nauka.

42. Grinchenko, B.D. (1907-1909) Slovar' ukrainskogo yazyka [Dictionary of the Ukrainian language]. Vols 1-4. Kiev: USSR AS.

43. Dahl, V.I. (1955) Tolkovyy slovar' zhivogo velikorusskogo yazyka [Explanatory Dictionary of the Living Great Russian language]. Vols 1-4. Moscow: Gos. izd-vo inostr. i nats. slov.

44. Glebova, A.A. (2003) Domshinskaya beresta [Domsha birch bark]. In: Nauchnye chteniya pamyati V.M. Vasilenko [Scientific readings in memory of V.M. Vasilenko]. Vologda: VMDPNI.

45. Krylov, A. (2000) Ne kvasom zemlya polita: Primechaniya k "chelovecheskoy tragedii" Aleksandra Galicha [The ground is not watered with kvass: Notes to the "human tragedy" of Alexander Galich]. Lebed'. 25 June. [Online] Available from: http://lebed.com/ 2000/art2197.htm. (Accessed: 05.03.2018).

46. Bagrinovskiy, G.Yu. (2001) O vine i p'yanstve: Russkie poslovitsy i pogovorki [About wine and drunkenness: Russian proverbs and sayings]. Moscow: Agraf. 